\title{
On-Farm Evaluation and Demonstration of Different Feeding Technological Options for Beef Cattle Fattening in Adami Tulu Jidokombolcha District of East Shoa Zone
}

\author{
Aman Gudeto ", Mieso Guru, Tesfaye Alemu Tucho, Ashebir Worku, Genet Dadi, Frehiwot Mesele, \\ Girma Debele
}

Oromia Agriculture Research Institute, Adami Tulu Agricultural Research Center, Ziway, Ethiopia

Email address:

amangude13@gmail.com (A. Gudeto)

${ }^{*}$ Corresponding author

To cite this article:

Aman Gudeto, Mieso Guru, Tesfaye Alemu Tucho, Ashebir Worku, Genet Dadi, Frehiwot Mesele, Girma Debele. On-Farm Evaluation and Demonstration of Different Feeding Technological Options for Beef Cattle Fattening in Adami Tulu Jidokombolcha District of East Shoa Zone. American Journal of Life Sciences. Vol. 8, No. 5, 2020, pp. 152-156. doi: 10.11648/j.ajls.20200805.20

Received: November 27, 2019; Accepted: December 24, 2019; Published: September 17, 2020

\begin{abstract}
Evaluation and demonstration study was conducted at Gerbi kebele of Adami Tulu Jidokombolcha district on twotwo and three year age old Borana bulls with the objectives of evaluation and demonstration of bulls fattening technologies at on-farm level. One farmer's research extension group (FREG) was formed for fattening the bulls. Twenty bulls were purchased from Borana zone by farmers for the fattening trials. Two feeding treatments $\left(\mathrm{T}_{1}=\right.$ Grazing $+20 \%$ crushed maize grain $+45 \%$ wheat bran $+35 \%$ Noug cake and $\mathrm{T}_{2}=$ Grazing $+65 \%$ wheat bran $+35 \%$ cotton seed cakes) were evaluated. The animals were randomly assigned for dietary rations and data on live weight change of the animals were taken using weight chart tape (developed by JICA project). Final body weights, total weight gain and average daily weight gain of the bulls were not significant $(\mathrm{P}>0.05)$ between the treatments. Bulls fed on treatment one attained an average daily weight gain of $0.83 \mathrm{~kg}$; while bulls fed on treatment two gained $0.76 \mathrm{~kg}$ per day. Total gross margin of treatment one $(53,154.5 \mathrm{ETB})$ was higher than treatment two $\left(49,467.75\right.$ ETB). Cost-benefit analysis indicated that feeding option number one $\left(T_{1}\right)$ is more economical as compared to bulls fed on $\mathrm{T}_{2}$. However, fatteners can use any of the feeding options depending on availability of the ingredients in their area.
\end{abstract}

Keywords: Young Borana Bulls, Beef Fattening, East Shoa, Technology Demonstration

\section{Background and Justification}

Ethiopia holds the largest livestock population in Africa, which is estimated at 59.5 million heads of cattle, 30.7 million heads of sheep and 30.2 million heads of goats [1]. The livestock sector contributes about $15 \%$ of the total export earnings and $30 \%$ of agricultural employment (source). Despite the importance of cattle among the farming communities and to the national economy at large, this sector has remained underdeveloped and in many cases underutilized [2]. Ethiopia's beef productivity per head/annual is $108.4 \mathrm{~kg}$ which is far less than $119 \mathrm{~kg}$ for Sudan, 146 for Kenya and $205 \mathrm{~kg}$ for whole world [3-5]. The current per capita consumption of meat is $13.9 \mathrm{~kg} /$ year, being lower than the African and the world per capita averages, which are $27 \mathrm{~kg} /$ year and $100 \mathrm{~kg} /$ year, respectively [6].

The meat currently produced from livestock production in the country could not satisfy the high increasing demand of people. On the other hand, the traditional livestock practices are not mostly market oriented [7]. Cattle fattening practices by farmers are mostly dependents on natural pasture and crop residues with few or no supplements. The fattening practices did not also account for the nutrient requirement of animals, the level of feeding being either above or below the animal requirements.

The government of Ethiopia is trying to expand the sector to meet the increased demand from both export and domestic markets. Inline to this, some fattening feed technological options are generated in Adami Tulu Agriculture Center. Recent reports indicated that growth performance of two 
years old Borana bulls evaluated using different dietary rations managed to attain $300 \mathrm{~kg}$ within 154 days of fattening period [8]. Evaluation and demonstration of such technologies is a way to promote to farmers and users.

Cattle fattening is a newly growing activity in Ethiopia. It is profitable system of rearing cattle to reduce poverty, unemployment and generate income for the rural people [9]. Small holder farmers practice oxen fattening after the completion of tillage [10]. Old cattle fattening is common practices with available feeds $[11,12]$. On other the line, the consumer preference of red meat (young animals) is increasing in the market. Therefore, young bulls fattening is an issue to meet red meat demand in the market. Borana cattle are well known breed among thirty four identified cattle breeds in Ethiopia and distributed in the southern parts of the Ethiopia [13]. Therefore, evaluation of growth performance of such breed with different feeding options at on-farm level is important to address to technologies to farmers. Hence, study was designed to evaluate and demonstrate different feeding technological options for twothree year age old Borana bulls to attain export market weight demand and to identify most economical feeding options at farmers' conditions.

\section{Materials and Methods}

\subsection{Experimental Sites Selection}

The study was conducted in selected district of East Shoa Zone. East Shoa Zone is one administrative zones of Oromia Regional State, Ethiopia. The zone has an area of $10421 \mathrm{~km}^{2}$. There are 10 districts within East Shoa Zone. Adami Tulu Jidokombolcha (ATJK) is one East Shoa Zone district where the demonstration took place. ATJK is located in mid-rift valley at $167 \mathrm{~km}$ from Addis Ababa city, Ethiopia at an altitude of 1650 above sea level, along the main road to Hawassa town. The district is geographically located at latitude of $7^{0} 50^{\prime} \mathrm{N}$ and longitude of $38^{\circ} 42^{\prime} \mathrm{E}$. Kemo Gerbi kebele was purposely selected with livestock expert of ATJK district. Farmers' cattle fattening history, access to road, market and water availability for cattle are some criteria used during site selection.

\subsection{Farmers' Selection and Capacity Building}

The activity was conducted using the farmers' research extension group (FREG) approaches. One farmer research group was organized. Farmers were selected based on their willingness to participate and previous experience in cattle fattening. Farmers contributed money to purchase bulls, grazing land, construct fattening shade and labor for the fattening purpose. Adami Tulu Agriculture Research Center provided dietary ration (concentrate feeds) and technical aids during the fattening exercise. Theoretical and practical training were provided for farmers, district livestock development expert and development agents on mixed ration preparation, feeding management, animals' health keeping, bulls fattening and marketing the finished bulls.

\subsection{Experimental Animals' Selection and Feeding Management}

Ages of the bulls were determined by dentition techniques. Accordingly, the bulls were two-two and half years old with an average initial live weight of $216.6 \pm 12.9 \mathrm{~kg}$. A total of twenty bulls were purchased from Borana Zone of Oromia Regional State, Ethiopia. They were transported by truck to study site. They were treated against internal and external parasites before the commencement of the fattening trial. All experimental bulls were randomly assigned to one of the two dietary treatment groups as indicated below in the next section. They stayed on adaptation to feeds for fifteen days before the 90 actual feeding days. The animals were supplied with their daily dietary ration amount; half in the morning and the remaining half in the afternoon. The concentrate feeds were given to the animals at a rate of $2.5 \%$ of their body weights and adjusted on every 15 days weight change. Bulls were kept on grazing for eight hours a day plus few tinning of maize crop whenever available and watering was freely or adlibtum during the whole day.

\subsection{Experimental Ration Formulation}

Dietary rations were formulated from different feed ingredients; wheat bran, Noug seed cake, crushed maize grain and cotton seed cake. Two dietary rations were formulated in such a way that they contain similar amounts of energy and protein. Treatment $1=$ Eight hour grazing $+20 \%$ maize grain + $45 \%$ wheat bran $+35 \%$ Noug seed cake. Treatment 2=Eight hour grazing $+35 \%$ cotton seed cake $+65 \%$ wheat bran. One kilogram salt was mixed in $100 \mathrm{~kg}$ dietary ration of each treatment.

\subsection{Chemicals Composition of Experimental Feeds}

Table 1. Ingredients and chemical composition (\%).

\begin{tabular}{lllll}
\hline Dietary ration & Ingredient & DM & CP & TDN \\
\hline \multirow{4}{*}{$\mathrm{T}_{1}$} & Maize grain $(10,85)$ & 20 & 2.00 & 17.00 \\
& Wheat bran $(13,67)$ & 45 & 5.85 & 30.15 \\
& Noug cake $(29.75,66)$ & 35 & 10.41 & 23.10 \\
& Total & 100 & 18.26 & 70.25 \\
& Wheat bran $(13,67)$ & 65 & 8.45 & 43.55 \\
$\mathrm{~T}_{2}$ & Cottonseed cake $(28,75)$ & 35 & 9.80 & 18.25 \\
& Total & 100 & & 69.8 \\
\hline
\end{tabular}

$\mathrm{Th}=$ Treatment, $\mathrm{DM}=$ Dry matter, $\mathrm{CP}=$ Crude protein, $\mathrm{TDN}=$ Total digestible nutrient.

\subsection{Growth Performance Assessment}

Record sheets and check lists were prepared to collect data on the amount of feed offered and fortnightly live weight changes. The total and average daily body weight gain was calculated as follows:

$$
\begin{gathered}
\mathrm{ADW}=\mathrm{ADW}=\frac{(F B W-I B W)}{\mathrm{D}} \\
\mathrm{TWG}=\mathrm{FBW}-\mathrm{IBW}
\end{gathered}
$$

Where: $\mathrm{ADG}=$ Average daily gain, $\mathrm{TWG}=$ Total weight 
gain, FBW=Final body weight, IBW=Initial body weight and $\mathrm{D}=$ Total fattening days

\subsection{Cost-benefit Ratio Analysis}

All variable costs incurred in conducting the trial were recorded. Total variable costs such as animal purchase, transportation, feeds cost, labor and veterinary costs were included in the cost-benefit analysis. At the end of the fattening period, the gross revenues were obtained from prices of the bulls sold at market. Fixed costs incurred for feeding the animals were not included in cost benefit analyses.

\subsection{Statistical Analysis}

Data was coded and entered to micro soft excel 2007 and checked for any error. Data on all live weight changes and economic parameters were analyzed using t-test of Rsoftware 3.5.2 version.

\section{Results and Discussion}

\subsection{Growth Performance of Bulls}

Growth performances of the Borana bulls were analyzed after fattening period and final body weight, total and average daily weight gains of the bulls are as depicted in Table 2. The study results indicate that there is no statistically significant difference in final body weight between the two treatments $\left(T_{1}\right.$ and $\mathrm{T}_{2}$ ). Total and average daily weight gains for the experimental bulls didn't also showed significant difference between the two treatments at 105 days of fattening. This study indicated that the Borana bulls can attainexport market body weight demand in fiftween weeks of their fattening period.

Table 2. Growth performance of Borana bulls at on-farm level.

\begin{tabular}{llll}
\hline Weight & $\mathbf{T}_{\mathbf{1}}$ & $\mathbf{T}_{\mathbf{2}}$ & Overall \\
\hline IBW $(\mathrm{kg})$ & $214.3 \pm 10.9$ & $218.8 \pm 14.7$ & $216.6 \pm 12.9$ \\
FBW $(\mathrm{kg})$ & $301.6 \pm 7.8$ & $298.1 \pm 10.9$ & $300.3 \pm 9.4$ \\
TWG $(\mathrm{kg})$ & $87.3 \pm 5.2$ & $79.3 \pm 8.4$ & $83.8 \pm 7.7$ \\
ADG $(\mathrm{kg})$ & $0.83 \pm 0.07$ & $0.76 \pm 0.08$ & $0.79 \pm 0.07$ \\
\hline
\end{tabular}

$\mathrm{IBW}=$ Initial body weight, FBW=Final body weight, $\mathrm{ADG}=$ Average daily gain, $\mathrm{TWG}=$ Total weight gain, Values are not significant across raw at $P<0.05, \mathrm{~T}_{1}$ (eight hour grazing $+20 \%$ maize grain $+45 \%$ wheat bran $+35 \%$ Noug seed cake), $\mathrm{T}_{2}$ (eight hour grazing $+65 \%$ wheat bran $+35 \%$ cotton seed cake)

\subsection{Cost-Benefit Analysis}

The result of partial budget analysis of fattening the twotwo and three years age old Borana bulls fattening at on-farm level is given in Table 3. Even though, there was no significant difference between the treatments the result indicated higher total gross margin for experimental bulls fed dietary feed $\left(T_{1}\right)$ than those fed dietary ration $T_{2}$.

Table 3. Economic return from on-farm bulls fattening.

\begin{tabular}{llll}
\hline List of items & $\mathbf{T}_{\mathbf{1}}$ & $\mathbf{T}_{\mathbf{2}}$ & Overall \\
\hline Feeds costs per bull (ETB) & 4635.05 & 4798.425 & 4716.7375 \\
Purchasing price per bull (ETB) & 8500 & 8500 & 8500 \\
\hline
\end{tabular}

\begin{tabular}{llll}
\hline List of items & $\mathbf{T}_{\mathbf{1}}$ & $\mathbf{T}_{\mathbf{2}}$ & Overall \\
\hline Transport cost per bull (ETB) & 700 & 700 & 700 \\
Labor cost per bull (ETB) & 150 & 150 & 150 \\
Veterinary cost per bull (ETB) & 55 & 45 & 50 \\
Total variable cost per bull (ETB) & 14040.05 & 14193.425 & 14116.738 \\
Total gross output per bull (ETB) & 19355.5 & 19140.2 & 19247.85 \\
Gross margin per bull (ETB) & 5315.45 & 4946.775 & 5131.1125 \\
Total gross margin (ETB) & 53154.5 & 49467.75 & 51311.125 \\
\hline
\end{tabular}

ETB: Ethiopia Birr; Values are not significant across raw at $P<0.05, \mathrm{~T}_{1}$ (eight hour grazing $+20 \%$ maize grain $+45 \%$ wheat bran $+35 \%$ Noug seed cake), $\mathrm{T}_{2}$ (eight hour grazing $+65 \%$ wheat brain $+35 \%$ cotton seed cake).

\subsection{Farmers Perception}

The final body conditions of the bulls and farmers observations at field day were illustrated in the figure 1 and figure 2. Farmers shared their opinion on the ration basing their own observation on differences between their traditional fattening experience and current demonstration. They appreciated the processes involved animal selection criteria, feeding management, dietary ration preparation and the house construction. The fattening technology demonstrated perceived as easily manageable and profitable. They also considered the fattening work as income source farmers.

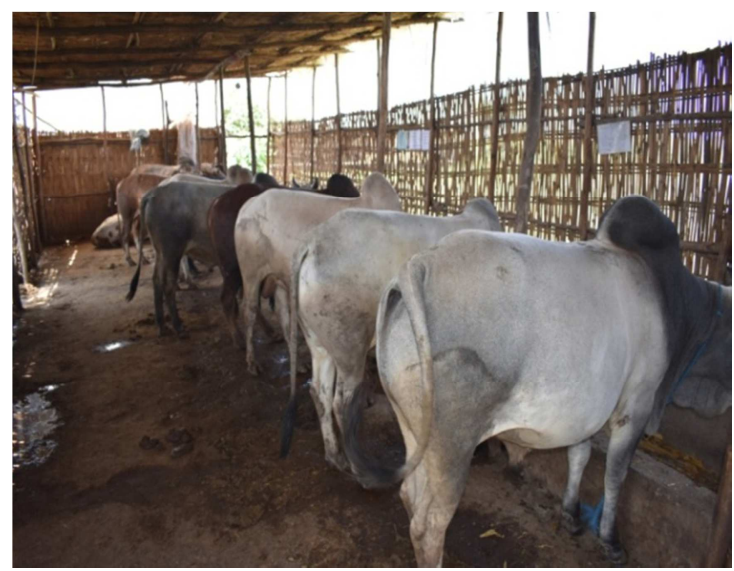

Figure 1. Bulls at fattening shade.

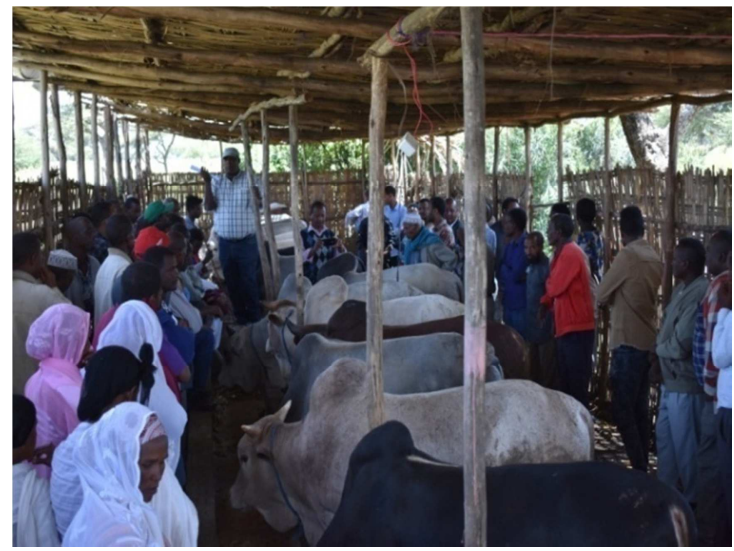

Figure 2. Farmers field days.

\section{Discussion}

There is no statistically significant difference in final body 
weight between the two treatments $\left(T_{1}\right.$ and $\left.T_{2}\right)$. This is similar to the finding of Mieso et al., [9] who conducted similar study on the yearling Borana bulls. Similarly, Girma et al., [8] reported that dietary rations have similar effect on final body weight of two years age old Borana bulls.

The total and average daily weight gains of Borana bulls were not stastically different between the the two groups. Similarly, studies conducted at on-station onyearling Borana bulls, two years old Borana bulls, yearling Kereyu bulls, two years old Kereyu bulls, yearling Arsi bulls and two years old Arsi bulls fed on similar dietary ration reported no significant differences in total weight gains among the treatment groups [8, 14-18]. The current average daily weight gains of the bulls at the end of the fattening period was found to be similar to the finding of Girma et al., [8] who reported a daily weight gain of 0.801 and $0.753 \mathrm{~kg}$ for two years old Borana bulls.

Young Borana bulls have better average daily weight gain when compare with some reports on the growth performance of some aged local breeds. The average daily weight gain $(0.51 \mathrm{~kg})$ of Arsi oxen fedon urea treated wheat straw and supplemented $4 \mathrm{~kg}$ concentrate per day for ninety days at Negele-Arsi district [19] was lower than the current finding. Similarly, the average weight gain of Arsi oxen which fed urea-molleses block attained $0.45 \mathrm{~kg}$ /day at East Shoa and West Arsi Zones [20]. Moreover, their also higher than average daily weight gain $(0.65 \mathrm{~kg})$ of old age Fogera oxen which was fed on concentrate feeds for 90 days [21].

The result indicates that young Borana bulls have potential to attain the export market weight $(250-300 \mathrm{Kg})$ at on-farm level. Previous study also conducted at Adami Tulu Research Center indicated that two years old Borana bulls attained the export market weight [8]. Similarly, study conducted on yearling Borana bulls which fed similar dietary rations at onstation were attained export market weight [14].

The partial budget analysis indicates the Borana bulls receive maize grain more gross margin than cotton seed cake. This study was similar to Mieso et al., [14] where the Borana bulls, which received crushed maize grain, gave better profit than those received cotton seedcake.

\section{Conclusion and Recommendation}

Twenty four two to three years old Borana bulls were randomly assigned on two dietary rations and kept on feeding for fifteen weeks. Growth performances of the bulls were assessed and there is no statistically significant difference in final body weight, total daily weight and daily weight gain between dietary rations, which may be attributed to the similarity of the CP and TDN of the ration provided to the experimental bulls. Numerically bulls fed on dietary $T_{1}$ were more profitable than bulls fed on dietary $\mathrm{T}_{2}$. However, as there were no significant differences in major parameters among the treatments, any one of the feeding options can be used depending on availability of the feed ingredients in the area.

\section{Acknowledgements}

The authors would like to thank, Ethiopian Institute of Agricultural Research (EIAR) for funding this activity financially through national beef commodity and Oromia Agricultural Research Institute (OARI) for the logistic support to accomplish the activity as well as the development agents and farmers for their valuable contribution during the entire course the on-farm feeding trial experimentation.

\section{References}

[1] Central Statically Agency (CSA), Ethiopia Sample survey Enumeration. Addis Ababa. Ethiopia. (2017).

[2] Mezgebe G, Gizaw Solomon, Urge Mengistu, Chavhan A. (2017). Begait cattle production systems and production performances in northern Ethiopia. Int. J. of Life Sciences. 5 (4): 506-516.

[3] Negassa A., Shahidur R., Gebremedhin B., "Livestock Production and Marketing in Ethiopia," Ethiopia Strategy Support Program II, ESSP II Working Paper, pp: 26-35. August, 2011.

[4] Mummed YY, Edward Cottington Webb (2015). Carcass quality audit-A strategy to improve beef sector in Ethiopia," African Journal of Agricultural Research. 10 (28): 2731-2737.

[5] Zekarias Seiko Minota, "The Impact of Foreign Direct Investment (FDI) on Economic Growth in Eastern Africa: Evidence from Panel Data Analysis," Applied Economics and Finance. 2016. 3 (1): 145-160.

[6] Belay Zeleke, Minale Getachew (2017). Traditional Cattle Husbandry Practice in Gamo Gofa Zone, Southern Western Ethiopia. International Journal of Novel Research in Life Sciences. 4 (5) p: 1-7.

[7] Tsigereda Fekadu, Mengistu Urge, Emebet Moreda (2016). Assessment of Traditional CattleFattening Practices in Hararghe Highland Parts of Ethiopia. World journal of agricultural science. 12 (2) p: 149-160.

[8] Girma Debele, Mieso Guru, Tesfaye Alemu Tucho, Arse Gebeyehu, Frehowit Messele, Ashebir Worku, Aman Gudeto (2015). Effect of different feeds option on growth response and carcass characteristic of two years aged Borana bulls for export market weight gain at Adami Tulu Agricultural Research Center. Basic Research Journal of Agricultural Science and Review. 4 (5) p: 139-145.

[9] Kassahun Ahmed, Berhan Tamir, Ashenafi Mengistu (2017). Constraints, opportunities and motives of cattle fattening practices in urban and peri-urban kebeles of Kombolcha town, South Wollo Zone, Ethiopia. Agriculture and Biology Journal of North America. ISSN Print: 2151-7517, ISSN Online: 2151-7525.

[10] Gebreselassie N (2018). Review on Beef Cattle Production and Marketing System in Ethiopia. Journal of Fisheries \& Livestock Production. J Fisheries Livest Prod. 6 (3) DOI: 10.4172/2332-2608.1000277.

[11] DAGRIS (Domestic Animal Genetic Resources Information System), International Livestock Research Institute, Addis Ababa, Ethiopia. Accessed date, April 9, 2018 http://eth.dagris.info/species/85/breeds. 
[12] Shewangizaw Wolde, Zekarias Bassa, Tesfaye Alem (2014). Assessment of cattle fattening and marketing system and constraints affecting cattle fattening in Central Southern Region of Ethiopia. African Journal of Agriculture Research. 9 (41), p. 3050-3055.

[13] Ahmed K, Tamir B, Mengistu A. (2017). Cattle selection criteria and fattening practices in urban and peri-urban Kebeles of Dessie and Kombolcha Towns, Ethiopia. Online J. Anim. Feed Res. 7 (2) p: 29-37.

[14] Mieso Guru, Girma Debele, Tesfaye Alemu Tucho, Frehiwot Mesele, Tesfaye Alemu Aredo (2013). Evaluation of different feeding options on yearling Borana bulls to attain export market weight at Adami Tulu Agricultural Research Center," American Journal of Cell and Animal Biology. 1 (1) p: 01-09.

[15] Tesfaye Alemu Tucho, Tesfaye Alemu Aredo, Girma Debele, Mieso Guru, Ashebir Worku, Aman Gudeto, Frehowit Messele (2018). Evaluation of different dietary rations for growth performance and carcass characteristics of two years old Kereyu bulls for export/local market weight. Basic Research Journal of Agricultural Science and Review. 6 (6). p: 49-56.

[16] Ashebir Worku, Tesfaye Alemu, Mieso Guru, Aman Gudeto, Frehiwot Mesele, Genet Dadi (2019). Evaluation of different feeding options on growth response and carcass characteristic of yearling Kereyu-Bulls to attain local/export market weight. Int J Agric Sc Food Technol. 5 (2) p: 050-053.
[17] Tesfaye Alemu, Ashebir Worku, Genet Dadi, Mieso Guru, Aman Gudeto (2019). Evaluation of different feeding options for growing two years old Arsi-Bulls to attain export market weight. Basic Research Journal of Agricultural Science and Review. 7 (1). P. 11-17.

[18] Aman Gudeto, Tesfaye Alemu, Mieso Guru, Ashebir Worku, Genet Dadi (2019). Evaluation of Different Feeding Options for Yearling Arsi Bulls to Attain Export Market Weight. Journal of Biology, Agriculture and Healthcare. 19 (14). ISSN 2224-3208.

[19] Mieso G, Girma D, Tesfaye A, Aman G, Ashebir W, Frehiwot M, "On-farm demonstration of urea wheat straw based cattle fattening at Negele-Arsi district of West Arsi Zone," Proceeding of review workshop on completed research activities of livestock directorate held at Agricultural research center, Adami Tulu, Ethiopia, p. 33-38, 4-8 Sep, 2017.

[20] Nabi Husein, Dawit Abate, Lalisa Diriba, Masarat Xilahun (2018). Pre Scaling Up of Urea Molasses Block Technology to Fatten Arsi Oxen in West Arsi and East Shewa Zone of Oromia Regional State, Ethiopia. Journal of Biology, Agriculture and Healthcare. 8 (15). ISSN 2225-093X.

[21] Adebabay Kebede, Addisu Bitew, Tewodros Bimrew, Asresu Yitayew, Yihalem Denekew, Yeshiwas Ferede, Getinet Zeleke (2013). Comparative Evaluation of the Fattening Performance of Fogera and Adet Old Oxen at Andassa Livestock Reseach Center, Ethiopia. Int. J. Pharm. Med. \& Bio. Sc. 2 (4). 